\title{
FUNGICIDES FOR THE CONTROL OF SCLEROTINIA IN TOMATOES FOR PROCESSING
}

\author{
G. W. Woon \\ Ivon Watkins-Dow Ltd., Hastings
}

Summary

Trial results from field studies over the past two seasons are presented. Three new fungicides, thiophanate-methyl, dichlozoline and benomyl were evaluated for the control of Sclerotinia sclerotiorum and Sclerotinia minor. All three fungicides significantly reduced the amount of infection, with dichlozoline showing the greatest activity. In most instances good control of Sclerotinia rot was accompanied by significant yield increases in tomatoes.

\section{INTRODUCTION}

THE DISEASE, sclerotinia rot, caused by the fungi Sclerotinia sclerotiorum (syn. S. major) and S. minor, has become a serious disease in processing crops of dwarf tomatoes in Hawke's Bay. Crop rotation has been carried out in an attempt to reduce build-up of the disease. This has been of very limited success because Sclerotinia have many host crops, and because the sclerotia have a long soil life (Rainbow, 1970). Soil fumigation with chloropicrin has been unsuccessful. Polythene mulching to reduce the spread of spores has given up to $50 \%$ control but is uneconomic (Eade and Corbin, 1970). This paper presents the results of field trials in dwarf tomatoes over the past two seasons with three new fungicides, dichlozoline, thiophanate-methyl and benomyl.

\section{EXPERIMENTAL}

One trial was laid in the spring of 1969 and three trials in 1970. Plots were established in commercial tomato crops, variety Scoresby, in fields known to have a previous history of Sclerotinia infection. Replicated small plot broadcast applications were made with a 2-nozzle hand boom applying over each row 100 gal of water per sprayed acre at $40 \mathrm{lb} / \mathrm{sq}$.in. and $2 \mathrm{mph}$. In Trial 1 a handgun was used applying 100 to $150 \mathrm{gal}$ of spray mix per acre at $40 \mathrm{lb} / \mathrm{sq}$.in. Rates of application are expressed as $1 \mathrm{~b}$ active ingredient per sprayed acre.

Identification of plants showing infection "strike" by either $S$. sclerotiorum or $S$. minor were made by splitting the whitened stems and by identifying the sclerotia present. In Trial 3, the numbers of apothecia present on the soil surface were counted during the major disease buildup period by lifting one side of the plants in the left-hand row.

Trial 1 (Hastings. Planted 17/11/69)

Applications were made to plants 6 to 7 in. in height in active vegetative growth, beginning 2 weeks after transplanting. Each treatment was replicated 4 times using plots two rows wide with 20 plants per row. Treatment dates were as follows:

Left-hand row: 29/11/69, 12/12/69*, 23/12/69, 7/1/70, 20/1/70.

Right-hand row: 12/12/69*, 23/12/69, 7/1/70, 20/1/70.

*Treatments with dichlozoline were commenced on this date. 
All evaluations and yield were made on left-hand rows leaving right-hand rows to compare the effect of plant handling on infection. Five harvests of fruit were made between March 2 and March 31 .

Trial 2 (Hastings. Planted 24/10/70)

Applications were made to transplants 4 to $5 \mathrm{in}$. in height in active vegetative growth one week after transplanting. Each treatment was replicated 6 times using plots containing three rows of plants with 10 plants per row. Treatments were applied on $2 / 11 / 70,17 / 11 / 70,1 / 12 / 70$, $16 / 12 / 70$. Five harvests from the middle row were made between $19 / 1 / 71$ and $1 / 3 / 71$.

Trial 3 (Hastings. Planted 24/10/70)

Applications were made to plants beginning two weeks after transplanting. Plants were 5 to $6 \mathrm{in}$. in height, beginning active growth, and showed no evidence of disease. Each treatment was replicated 4 times using plots containing three rows of plants with 13 plants per row. Treatments were applied on $6 / 11 / 70,20 / 11 / 70,1 / 12 / 70,16 / 12 / 70$. Five harvests were made between $22 / 1 / 71$ and $23 / 2 / 71$.

Trial 4 (Hastings. Planted 24/10/70)

Applications were made to fully grown plants with ripening fruit prior to the first pick. A dense mat of mycelia was present under all plants, with laterals and fruit beginning to show infection. Apothecia were also present. Treatments were applied on $8 / 1 / 71$ and $16 / 1 / 71$ just prior to the first pick on January 19. Plots were single rows of 10 plants replicated 4 times and randomized throughout the trial area. Five picks were made through to March 1.

\section{RESULTS}

TRIAL 1

The degree of infection and tomato yields are presented in Table 1.

TABLE 1: INFECTION AND YIELDS, TRIAL 1

\begin{tabular}{|c|c|c|c|c|c|c|c|}
\hline $\begin{array}{l}\text { Treatment } \\
\quad(I b)\end{array}$ & Weeks & $\begin{array}{l}\% \\
s f r \\
12\end{array}$ & $\begin{array}{l}\text { nfected } \\
\text { m First } \\
14\end{array}$ & $\begin{array}{l}\text { Plan } \\
\text { App } \\
16\end{array}$ & $\begin{array}{l}\text { lication } \\
18\end{array}$ & $\begin{array}{l}\text { Mean } \\
\text { "Strikes" } \\
\text { per Plant }\end{array}$ & $\begin{array}{c}\text { Yield } \\
\text { (tons/ } \\
a c)\end{array}$ \\
\hline dichlozoline 0.5 & 0 & 0 & 0 & 0 & 0 & 0 & 17.0 \\
\hline benomyl 0.5 & 0 & 0 & 3.8 & 20 & 49 & 0 & 16.0 \\
\hline thiophanate-methyl 0.5 & 2 & 2 & 9 & 58.5 & 75 & 2.0 & 15.4 \\
\hline $\begin{array}{l}\text { Untreated control } \\
\text { CV }\end{array}$ & 2.5 & 6 & 66 & 97.5 & $\begin{array}{l}100 \\
16.4 \%\end{array}$ & 5.0 & $\begin{array}{l}11.6 \\
24.5 \%\end{array}$ \\
\hline
\end{tabular}

In this trial, $S$. sclerotiorum was present up to 12 wceks from the first treatment but the infection caused only a low level of complete plant collapse. From then on all infections were from $S$. minor. In the early part of the season, both dichlozoline and benomyl gave $100 \%$ control of $S$. sclerotiorum compared with $6 \%$ infected plants in untreated controls. As the season advanced, dichlozoline continued to give $100 \%$ control of both $S$. sclerotiorum and $S$. minor up to the end of harvest. Benomyl gave complete control of $S$. sclerotiorum but held only $50 \%$ of the plants free from lateral infection by $S$. minor. No increase in disease was noted owing to handling of the plants or harvest. The dichlozoline plots had the 
highest incidence of tomato spotted wilt which undoubtedly reduced the potential yield increase expected from the high level of Sclerotinia control obtained. Thiophanate-methyl gave an earlier peak yield than the other treatments.

TRIAL 2

Counts of plant infection and tomato yields are presented in Table 2.

TABLE 2: INFECTION AND YIELDS, TRIAL 2

\begin{tabular}{lccc}
\hline $\begin{array}{c}\text { Treatment } \\
(l b)\end{array}$ & $\begin{array}{c}\text { M Moanths } \\
\text { Mean Lateral } \\
\text { "Strikes" } \\
\text { per Plant }\end{array}$ & $\begin{array}{c}\text { of Harvest) } \\
\text { Infected } \\
\text { Plants } \\
(\%)\end{array}$ & $\begin{array}{c}\text { Yield } \\
\text { tons/ac) }\end{array}$ \\
\hline dichlozoline 0.5 & 0.02 & 1.5 & 28.0 \\
dichlozoline 1.0 & 0 & 0 & 28.3 \\
thiophanate-methyl 1.0 & 0.1 & 6 & 28.7 \\
benomyl 1.0 & 0.1 & 10 & 26.7 \\
Untreated control & 0.5 & 28 & 22.0 \\
CV & & $24.0 \%$ & $16.7 \%$ \\
\hline
\end{tabular}

Disease build-up was slow, reaching a comparatively low level of $28 \%$ infected plants in controls at the end of harvest. Mainly S. sclerotiorum was present with only 10 to $15 \% \mathrm{~S}$. minor in the trial area. All treatments gave increased yields over control with a worthwhile reduction of Sclerotinia infection. Dichlozoline $(0.5$ and $1.0 \mathrm{lb})$ gave almost complete control of both S. minor and S. sclerotiorum. Thiophanate-methyl gave an earlier peak yield than other treatments. The trial area suffered heavily with late blight (Phytophthora infestans) and leaf mould (Cladosporium fulvum) towards the end of harvest, with all treatments visually preventing leaf mould a week longer than the controls.

Trial 3

Counts of apothecia, plant infection and tomato yields are presented in Table 3.

TABLE 3: INFECTION AND YIELDS, TRIAL 3

\begin{tabular}{|c|c|c|c|c|}
\hline $\begin{array}{l}\text { Treatment } \\
\quad(\mathrm{lb})\end{array}$ & $\begin{array}{c}\text { Weeks fr } \\
\text { Applic } \\
10 \\
\text { Mean } \\
\text { Apothecia } \\
\text { per } 5 \text { sq.ft } \\
\text { of row }\end{array}$ & $\begin{array}{l}\text { om First } \\
\text { ations } \\
15 \text { (end of } \\
\text { harvest) } \\
\text { Mean } \\
\text { "Strikes" } \\
\text { per } \\
\text { Plant }\end{array}$ & $\begin{array}{c}\text { Infected } \\
\text { Plants } \\
(\%)\end{array}$ & $\begin{array}{c}\text { Yield } \\
\text { (tons/ac) }\end{array}$ \\
\hline $\begin{array}{l}\text { dichlozoline } 0.5 \\
\text { dichlozoline } 1.0 \\
\text { thiophanate-methyl } 1.0 \\
\text { Untreated control } \\
\text { CV }\end{array}$ & $\begin{array}{c}0.6 \\
1.0 \\
11 \\
12.2\end{array}$ & $\begin{array}{l}0.2 \\
0 \\
2.8 \\
3.0\end{array}$ & $\begin{array}{l}10 \\
0 \\
77 \\
83 \\
42.4 \%\end{array}$ & $\begin{array}{l}25.4 \\
26.3 \\
28.1 \\
19.7 \\
9.6 \%\end{array}$ \\
\hline
\end{tabular}


Both $S$. sclerotiorum and $S$. minor were present in the trial area with the control plot having $80 \%$ S. minor and $20 \%$ S. sclerotiorum "strikes". Dichlozoline $(0.5$ and $1.0 \mathrm{lb})$ gave a high degree of control of both $S$. minor and S. sclerotiorum. Dichlozoline also suppressed apothecia emergence. Marked yield increases were recorded from all treatments. Even thiophanate-methyl showed an increased yield despite the limited disease control achieved. The trial area suffered heavily with late blight and leaf mould towards the end of harvest. All treatments visually prerented infection of leaf mould a week longer than untreated controls.

Trial 4

Counts of plant infection and yield of tomatoes 2 months after the first application of dichlozoline are presented in Table 4 .

TABLE 4: INFECTION AND YIELDS, TRIAL 4

\begin{tabular}{|c|c|c|c|}
\hline $\begin{array}{l}\text { Treatment } \\
\quad(1 b)\end{array}$ & $\begin{array}{c}\text { Mean No. } \\
\text { Lateral } \\
\text { "Strikes" } \\
\text { per Plant }\end{array}$ & $\begin{array}{c}\text { Infected } \\
\text { Plants } \\
(\%)\end{array}$ & $\begin{array}{c}\text { Yield } \\
\text { (tons/ac) }\end{array}$ \\
\hline dichlozoline 0.5 & 0.2 & 17 & 19.9 \\
\hline dichlozoline 1.0 & 0.3 & 20 & 18.1 \\
\hline dichlozoline 2.0 & 0.1 & 10 & 20.4 \\
\hline Untreated control & 3.0 & 90 & 14.2 \\
\hline CV & & $35.0 \%$ & $8.1 \%$ \\
\hline
\end{tabular}

Only $S$. minor was present in the trial area at harvest. Dichlozoline has shown good activity inhibiting entry of the disease into the laterals of the plants even at this late treatment stage. There was little difference in disease control between $0.5 \mathrm{lb}$ and $2.0 \mathrm{lb}$, all treatments showing good yield increases over control.

\section{DISCUSSION}

In all trials both $S$. sclerotiorum and $S$. minor have occurred in varying proportions. Sclerotinia sclerotiorum has appeared to strike early in the growing season (December/January) when sufficient moisture was available. Sclerotinia minor appears to become predominant once the plants have developed their full foliage canopy.

Applications of these "systemic" fungicides as full foliage coverage treatments at 10 to 14-day intervals from planting to flower set or to early fruit formation have given a high level of disease control.

Dichlozoline $(0.5 \mathrm{lb}$ and $1 \mathrm{lb})$ has shown in all trials to have outstanding activity against both $S$. sclerotiorum and $S$. minor. In Trial 3 it has markedly reduced the emergence of the apothecial stage of the fungus. When applied late, as in Trial 4, dichlozoline prevented infection from entering the laterals when mycelia and apothecia were already present.

Benomyl showed high activity against $S$. sclerotiorum but considerably less activity against $S$. minor. Thiophanate-methyl has shown some control of $S$. sclerotiorum but little control of $S$. minor. It has shown earlier peak yields, suggesting an advancement in fruit maturity or an increased early fruit set. 
It is apparent that a high level of control of sclerotinia rot does not necessarily result in a proportionate increased crop yield. This may be due to the presence or absence of a complex of other fungal diseases together with virus infection, to all of which tomatoes are particularly susceptible.

\section{CONCLUSIONS}

Dichlozoline $(0.5 \mathrm{lb})$ when applied to full coverage on a 10- to 14-day spray schedule from planting to fruit set shows great promise for the control of both $S$. sclerotiorum and $S$. minor in tomatoes. Benomyl $(1.0 \mathrm{lb})$ also shows excellent activity but mainly against $S$. sclerotiorum. Dichlozoline in particular is very specific to the control of Sclerotinia spp. Further field studies evaluating dichlozoline in mixtures with other fungicides to broaden the spectrum of disease control are suggested. Further field studies with dichlozoline and benomyl as late "sálvage" treatments are also warranted.

\section{ACKNOWLEDGEMENTS}

Grateful thanks are due to the staff of the Research Division, Ivon Watkins-Dow Ltd., to Dr J. B. Corbin of the University of Auckland for valuable comments on the trial programme and to growers P. Archibald and D. G. Walker who co-operated in making trial sites available.

\section{REFERENCES}

Eade, R. P.; Corbin, J. B., 1970: Amer. Phytopath. Soc. Fungicide \& Nematocide Tests, 26: 91.

Rainbow, A. F., 1970: N.Z. Il Agric., 121 (6): 58-62. 